\title{
Climate Change Challenges to Groundwater Resources: Palestine as a Case Study
}

\author{
Numan Mizyed \\ Civil Engineering Department, An-Najah National University, Nablus, Palestine \\ Email:mizyed@najah.edu
}

How to cite this paper: Mizyed, N. (2018) Climate Change Challenges to Groundwater Resources: Palestine as a Case Study. Journal of Water Resource and Protection, 10, 215-229.

https://doi.org/10.4236/jwarp.2018.102013

Received: December 20, 2017

Accepted: February 25, 2018

Published: February 28, 2018

Copyright (c) 2018 by author and Scientific Research Publishing Inc. This work is licensed under the Creative Commons Attribution International License (CC BY 4.0).

http://creativecommons.org/licenses/by/4.0/

(c) (i) Open Access

\begin{abstract}
In the Mediterranean region, climate change will result by 2100 in a temperature increase that most likely will range from $2^{\circ} \mathrm{C}$ to $2.7^{\circ} \mathrm{C}$, while annual precipitation will most likely reduce in the range of $3 \%$ to $10 \%$. This paper uses hydrological modeling of precipitation and evapotranspiration to evaluate the challenge to aquifer natural recharge considering Palestine as a case study. The study showed that the climate change impacts on aquifer recharge will vary according to the distributions of monthly precipitation and evapotranspiration in the recharge areas. The $2^{\circ} \mathrm{C}$ to $3^{\circ} \mathrm{C}$ increase in temperature could result in a reduction of $6 \%$ to $13 \%$ in aquifer annual recharge. Aquifer recharge was found to be sensitive to changes in precipitation as a reduction of $3 \%$ to $10 \%$ in annual precipitation could result in a reduction in annual recharge ranging from $3 \%$ to $25 \%$. It was observed that aquifers with recharge areas characterized by lower precipitation are more sensitive to precipitation reduction and thus groundwater resources will be negatively impacted more in these areas by climate change. Thus, climate change will reduce water availability in drier areas requiring adaptation measures through improving water management and rehabilitation of water infrastructure.
\end{abstract}

\section{Keywords}

Climate Change, Groundwater Recharge, Adaptation, Precipitation Reduction, Palestine

\section{Introduction}

\subsection{Water Resources in Palestine}

Groundwater is the primary source of domestic and agricultural water in Palestine. In the West Bank, water is drawn from three main aquifer systems: the eastern, northeastern, and western aquifers (Figure 1). Characteristics of these 

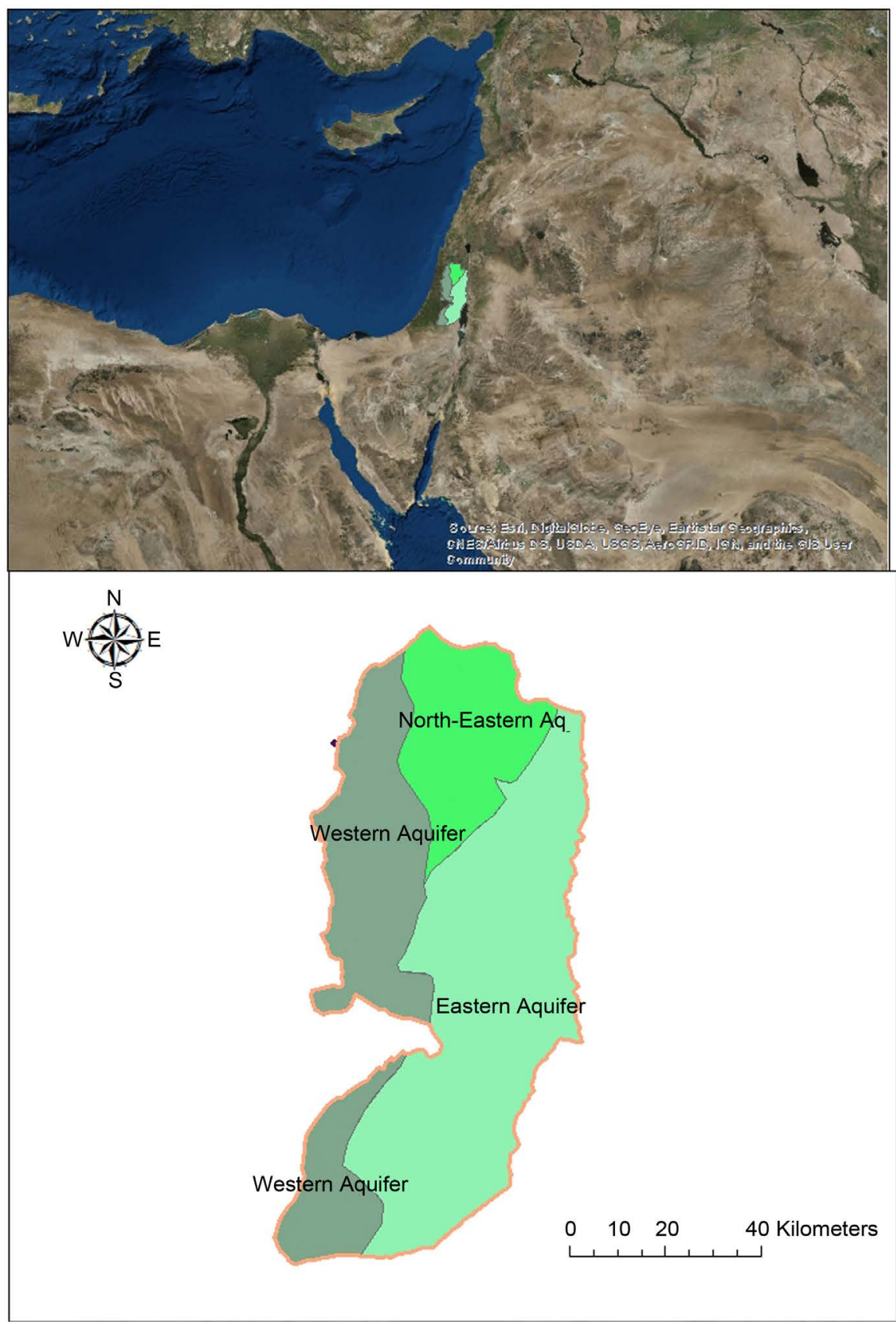

Figure 1. Groundwater aquifers in the west bank.

aquifers are shown in Table 1 . Their natural annual is estimated to range between 578 to $814 \mathrm{MCM} /$ year, as shown in Table 1 [1] [2]. Following Oslo accords, the Israeli-Palestinian Interim agreement of 1995 identified $679 \mathrm{MCM} /$ year as the average annual natural recharge of these aquifers. In Gaza, the main source of water is the coastal aquifer, which extends on the south-eastern side of the Mediterranean coast, with small parts of it extending under the Gaza strip. Natural recharge for the coastal aquifer in Gaza is estimated at $55 \mathrm{mcm} /$ year. However, the increasing domestic and agricultural demands for more than 1.5 million people in Gaza result in withdrawal of nearly $180 \mathrm{mcm} /$ year from that 
Table 1. Characteristics and natural recharge of aquifer systems in the west bank [1] [2].

\begin{tabular}{|c|c|c|c|c|}
\hline Aquifer system & $\begin{array}{l}\text { Western } \\
\text { aquifer }\end{array}$ & $\begin{array}{c}\text { Northeastern } \\
\text { aquifer }\end{array}$ & $\begin{array}{l}\text { Eastern } \\
\text { aquifer }\end{array}$ & Total \\
\hline \multicolumn{5}{|c|}{ Natural characteristics } \\
\hline Area $\left(\mathrm{km}^{2}\right)$ & 1767 & 981 & 2896 & 5644 \\
\hline $\begin{array}{l}\text { Average natural recharge } \\
\text { (MCM/year) }\end{array}$ & $318-430$ & $135-187$ & $125-197$ & $578-814$ \\
\hline \multicolumn{5}{|c|}{$\begin{array}{c}\text { Utilization according to Schedule 10, Article } 40 \text { of the } 1995 \text { Israeli Palestinian } \\
\text { Interim Agreement-ANNEX III }\end{array}$} \\
\hline Israeli utilization (MCM/year) & 340 & 103 & 40 & 483 \\
\hline Palestinian utilization (MCM/year) & 22 & 42 & 54 & 118 \\
\hline $\begin{array}{c}\text { Additional quantity for } \\
\text { development (MCM/year) }\end{array}$ & & & 78 & 78 \\
\hline Total quantity (MCM/year) & 362 & 145 & 172 & 679 \\
\hline
\end{tabular}

aquifer [1], leading to sea water intrusion and significant deterioration of water quality.

According to statistics of the Palestinian Water Authority (PWA), the total domestic water supply for the nearly 2.4 million Palestinians living in the West Bank was estimated at $88 \mathrm{MCM} / \mathrm{year}$ in 2011. This supply of water is less than demanded as demonstrated in frequent shortages, especially during the summer months, throughout West Bank towns and cities. Gaza receives $98 \mathrm{MCM} /$ year, however, given the high losses in the system, only about $55 \mathrm{MCM} /$ year is consumed by the domestic sector there [1], however, the water quality there has deteriorated, with high concentrations of dissolved solids.

Water demand is expected to increase considerably as a result of increasing population and improving socio-economic conditions. Natural population growth rates are estimated at $2.6 \%$ and $3.5 \%$ in the West Bank and Gaza, respectively [3]. Even if these rates are reduced to $2 \%$, the population will double by 2050 , to reach about 8 million people. Thus, domestic water demand rates are expected to double by 2050 resulting in severe water shortages requiring measures to bridge the gap between supply and demand.

\subsection{Climate Change}

As a result of human activity, significant increases in global atmospheric concentrations of carbon dioxide, methane and nitrous oxides have been observed since the industrial revolution [4]. Climate change is a direct outcome of the increased concentrations of greenhouse gasses in the atmosphere. The changes in climate are now evident from observations of increasing global average air and ocean temperatures, widespread melting of snow and ice, rising global mean sea level and changes in precipitation amounts, frequencies and intensities [4] [5]. Regional and global climate models have shown an increase in temperature ranging from $0.6^{\circ} \mathrm{C}$ to $4^{\circ} \mathrm{C}$ in the Mediterranean region. Considering the uncer- 
tainties in model estimates, it is most likely that the increase in temperature will range from $2^{\circ} \mathrm{C}$ to $2.7^{\circ} \mathrm{C}$ (the $25^{\text {th }}$ and $75^{\text {th }}$ percentiles, respectively). The changes in precipitation are expected to vary with a wider range of uncertainty in the Mediterranean region with possible reduction in annual precipitation reaching up to $19 \%$. The most likely range of annual precipitation reduction was estimated to be between $3 \%$ and $10 \%$ (the $25^{\text {th }}$ and $75^{\text {th }}$ percentiles, respectively) according to Christensen et al., [6].

The rising temperature will increase both evaporation and water needs and result in increasing desertification and aridity in the region. The change in precipitation will also have important impacts on the availability of water for agriculture in the region. The reduction in available water resources will impact water supplies for the domestic sector and the irrigated agricultural sector. Water policies must be adjusted to respond to climate change; water scarcity indicators should be linked to relevant adaptation strategies and socially and economically sensitive policies must be prioritized [7].

Considering the effects of climate change on increasing temperature and reducing precipitation, it is important to quantify these effects on the availability of groundwater by estimating their effects on the natural recharge of these resource aquifers. Their quantification has great importance for Palestinians as they evaluate their options for bridging the gaps between water supply and its demand.

\section{Methodology}

This study began with developing a hydrologic water balance model that defines the baseline conditions to estimate and model existing average natural recharge of groundwater aquifers in the West Bank. To accomplish this objective, available precipitation data was collected from 65 rainfall gages and climatic data was also collected from the 11 weather stations available in the West Bank. Figure 2(a) shows the spatial distribution of annual rainfall in the West Bank utilizing the data obtained from these 65 stations. Using average monthly weather data at the available 11 weather stations in the West Bank, monthly potential evapotranspiration rates were estimated at these stations using FAO CROPWAT computer model [8]. Penman-Montieth method was utilized in estimating potential evapotranspiration in accordance with FAO guidelines shown in FAO irrigation and drainage paper 56 [9]. These monthly values were integrated over time to obtain annual potential evapotranspiration at these stations. Based on the results, annual evapotranspiration spatial distribution is shown in Figure 2(b).

Land use patterns were analyzed and grouped into six categories including: olives, grapes, field crops, irrigated lands, built areas and pasture lands. Pasture (or unused) land is the most common in the West Bank. This land is usually unsuitable for cultivation due to steep slopes, excess rock outcroppings, or shallow soil, common in the middle and western parts of the West Bank. Land with low precipitation in the eastern slopes are also classified as pasture (grazing) 


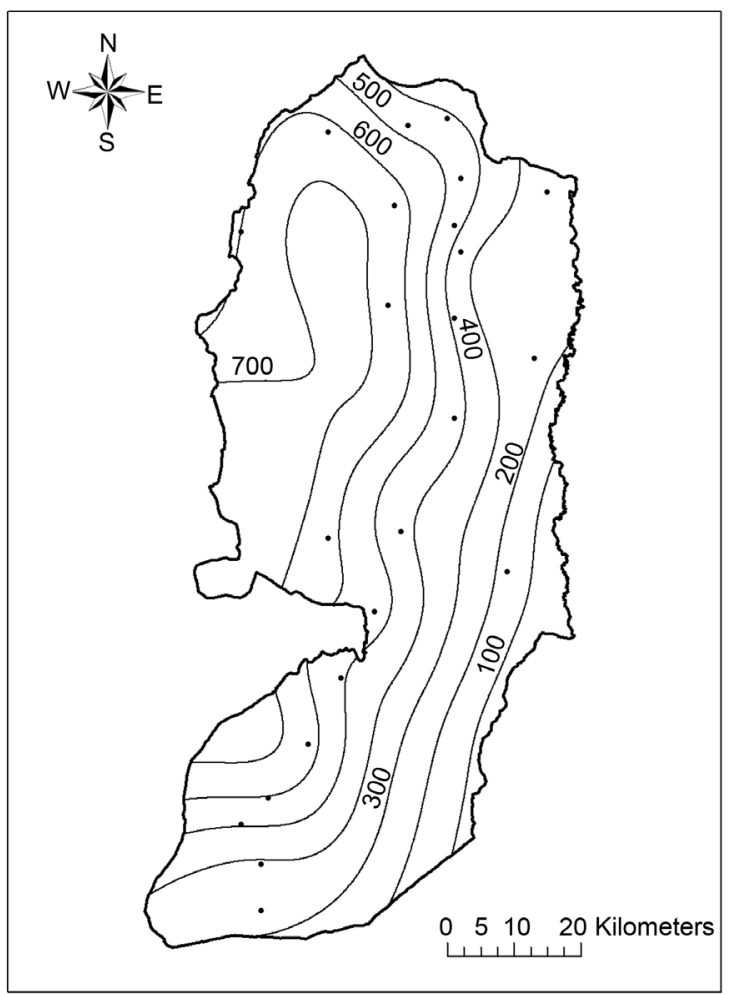

(a)

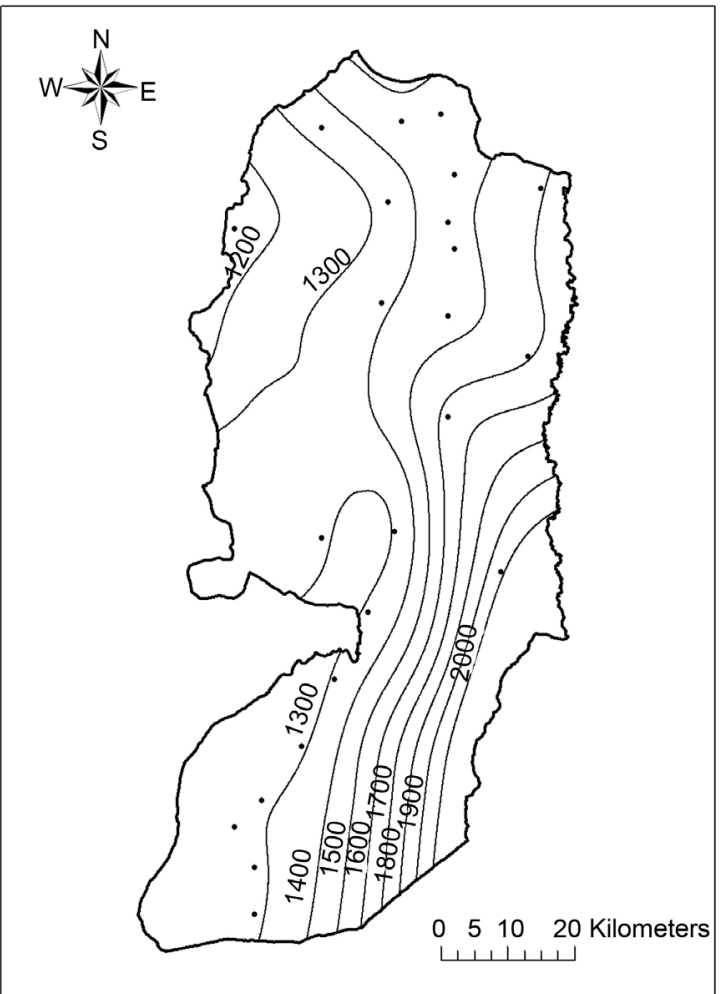

(b)

Figure 2. (a) Annual precipitation ( $\mathrm{mm}$ ) and (b) Potential annual evapotranspiration $(\mathrm{mm})$ spatial distribution in the West Bank. 
land. Precipitation there is insufficient to support rain-fed agriculture: olives are the most commonly cultivated crop in throughout the West Bank.

Using available land use maps and the locations of the rain gages and weather stations, the West Bank was divided into spatial cells representing land uses and climate variables. Utilizing values of monthly potential evapotranspiration for referenced crops, estimated using FAO-CROPWAT computer program and monthly precipitation data, and available data for cropping systems and soils, the actual crop evapotranspiration rates for the different land uses were estimated at each spatial cell. The model utilized crop coefficients to estimate crop consumptive use from potential evapotranspiration, considering rainfall as the only source of water, the water storage capacity of the soils according to their depths, field capacities and permanent welting points, the model estimates actual crop consumptive use for the different crops commonly planted. This includes estimating crop water consumptive use for rain-fed olives and grapes (main trees in the area). For pasture lands, grasses were assumed to be the common crop; for field crops, wheat was taken as the dominant field crop in the West Bank. Crop consumptive uses of other field crops are not significantly different than those of wheat. Due to the limitation of water availability from rainfall, which occurs only during winter months, the variability in actual crop consumptive use was small among different crops. Actual crop consumptive use is always limited by the amount of annual precipitation and the water storage capacity of the soil. Thus, in areas with precipitation below $350 \mathrm{~mm}$, actual crop consumptive use was found to be, at most, equal to annual precipitation for lands planted with olives. For areas with precipitation in excess of $460 \mathrm{~mm}$, the maximum actual crop consumptive use was found to be 454, 332, 441 and $362 \mathrm{~mm}$ for olives, grapes, wheat, and pasture lands, respectively. These amounts include crop evapotranspiration in rainy months (winter) and the amount of water that the soil can store within the plant root depth in the end of the rainy season.

The last component of the hydrologic water balance model was to estimate and simulate runoff which was simplified using runoff ratio depending on the built up and impervious areas within the spatial cell under consideration within the hydrologic water balance model. The runoff ratio was adjusted to obtain the historical total average annual runoff volume of $164 \mathrm{MCM}$ for the West Bank [1]. The ground water recharge was calculated utilizing a volume water balance approach for each spatial cell. The recharge at any cell is estimated as the volume resulting from subtracting the volume of water used by the different land uses at the cell and the volume of runoff from the cell was subtracted from the total rainfall volume from that cell. Spatial integration of the volumes of recharge at the different cells gives the total volume of recharge for each aquifer basin.

The impacts of climate change were simulated using the following scenarios:

1) Increases in average monthly temperature of 2 and 3 degrees Celsius representing the $25^{\text {th }}$ and $75^{\text {th }}$ percentiles respectively for the expected increase in temperature in the Mediterranean area as predicted by Christensen et al., [6]. 
2) Reductions in annual precipitation of 3,6 and $10 \%$ for the $25^{\text {th }}, 50^{\text {th }}$ (median) and $75^{\text {th }}$ percentiles for the predicted changes in annual precipitation in the Mediterranean area as predicted by Christensen et al., [6].

3) An additional case of $15 \%$ reduction in annual precipitation was simulated to evaluate the impacts of potential extreme changes in precipitation on aquifer recharge considering that the maximum reduction in annual precipitation could reach $19 \%$ in the Mediterranean region.

The scenarios above were simulated in the hydrologic water balance model. Actual evapotranspiration values for the different vegetative covers at different spatial cells were estimated for each scenario above using FAO CROPWAT. The hydrologic water balance model was then used to estimate the natural recharge at each spatial cell covering the West Bank area. The total annual recharge was estimated by integrating the values of recharge at the different spatial cells over each aquifer to estimate the predicted values of natural recharge for each aquifer. The calculated values of annual recharge for each aquifer were compared with the existing natural recharge to evaluate the impact of climate change scenarios mentioned above.

\section{Results and Discussion}

Baseline (existing) Conditions: Based on available precipitation data, land uses and simulated crop evapotranspiration, the hydrologic water balance simulation of existing conditions showed annual hydrologic water balance for the aquifers in the West Bank as summarized in Table 2. These hydrologic simulations indicate that annual natural recharge rates for the northeastern, western and eastern aquifers were estimated at 140,328 and $167 \mathrm{mcm}$ /year respectively. The values adopted in Schedule 10 of Article 40-Annex III of the 1995 Palestinian-Israeli Interim agreement were 145, 362 and $172 \mathrm{mcm} /$ year for the Northeaster, western and eastern aquifers respectively [1] [2]. Thus, the results of water balance hydrologic analyses correlate very well to the most agreed upon estimates of recharge by Palestinians and Israelis.

A flow model for the eastern aquifer was developed by Guttman and Zukerman [10], in that model, the following empirical equations for recharge were derived:

$$
\begin{aligned}
& \mathrm{R}=0.8 \times(\mathrm{P}-360) \text { for } \mathrm{P}>650 \mathrm{~mm} ; \\
& \mathrm{R}=0.534 \times(\mathrm{P}-216) \text { for } 300<\mathrm{P}<650 \mathrm{~mm} ; \\
& \mathrm{R}=0.15 \times \mathrm{P} \text { for } \mathrm{P}<300 \mathrm{~mm} .
\end{aligned}
$$

The hydrologic water balance of this study correlated very well with the empirical model for areas with annual precipitation exceeding $300 \mathrm{~mm}$. The water balance evaluation shows that when annual precipitation is less than $300 \mathrm{~mm}$, the amount of recharge is negligible. Thus, the $15 \%$ recharge assumption by Guttman and Zukerman [10] appears to over-estimate recharge in these areas. At low annual precipitation areas (below $300 \mathrm{~mm}$ ) most precipitation is utilized by the vegetative cover (or evaporates from the bare soil) resulting in negligible 
Table 2. Summary of hydrologic water balance for the aquifers in the west bank.

\begin{tabular}{|c|c|c|c|c|c|c|c|c|}
\hline \multicolumn{9}{|c|}{ Annual budget as depths in $\mathrm{mm}$} \\
\hline Aquifer & Precipitation & $\begin{array}{c}\text { Olives } \\
\text { ET }\end{array}$ & $\begin{array}{l}\text { Grapes } \\
\text { ET }\end{array}$ & $\begin{array}{c}\text { Field } \\
\text { crops } \\
(\mathrm{ET})\end{array}$ & $\begin{array}{l}\text { Irrigated } \\
\text { lands ET }\end{array}$ & $\begin{array}{l}\text { Pasture } \\
\text { lands ET }\end{array}$ & Runoff & $\begin{array}{l}\text { Natural } \\
\text { recharge }\end{array}$ \\
\hline Northeastern & 546 & 438 & - & 411 & 324 & 336 & 40 & 147 \\
\hline Western & 564 & 422 & 325 & 385 & 318 & 336 & 44 & 183 \\
\hline Eastern & 327 & 423 & 319 & 345 & 214 & 242 & 17 & 58 \\
\hline Average & 440 & 426 & 323 & 391 & 259 & 273 & 30 & 113 \\
\hline \multicolumn{9}{|c|}{$\begin{array}{l}\text { Annual volumes of water utilized for crop evapotranspiration, runoff, natural recharge } \\
\text { and precipitation in MCM }\end{array}$} \\
\hline Aquifer & $\begin{array}{l}\text { Total } \\
\text { precipitation }\end{array}$ & $\begin{array}{c}\text { Olives } \\
\text { ET }\end{array}$ & $\begin{array}{l}\text { Grapes } \\
\text { ET }\end{array}$ & $\begin{array}{l}\text { Field } \\
\text { crops ET }\end{array}$ & $\begin{array}{l}\text { Irrigated } \\
\text { lands ET }\end{array}$ & $\begin{array}{l}\text { Pasture } \\
\text { lands ET }\end{array}$ & Runoff & $\begin{array}{l}\text { Natural } \\
\text { recharge }\end{array}$ \\
\hline Northeastern & 520 & 140.4 & 0.0 & 86.0 & 4.8 & 110.5 & 38.2 & 140.2 \\
\hline Western & 1015 & 278.7 & 17.8 & 20.3 & 27.5 & 263.3 & 79.3 & 328.5 \\
\hline Eastern & 938 & 117.0 & 6.7 & 30.6 & 29.0 & 537.6 & 49.7 & 167.9 \\
\hline Total & 2474 & 536.1 & 24.4 & 137.0 & 61.4 & 911.3 & 167.2 & 636.5 \\
\hline
\end{tabular}

recharge. Considering the long dry periods (more than 9 months in the eastern slopes where precipitation is below $300 \mathrm{~mm}$ ), soil is either air dry or at the welting point at the start of the rainy season. Thus, it will have a good capacity in holding most of the rainfall occurring in few rainfall storms during the short winter months. This moisture is lost by evaporation or transpiration in the dry periods for most soils in these areas. Recharge can occur if rainfall storms continue to occur before drying the soil to allow water to flow to the deeper layers away from the soil surface which is rare. Figure 3 shows the relation between annual precipitation and annual recharge at different sites in the West Bank. Figure 3 shows that annual recharge becomes insignificant when annual precipitation is less than $300 \mathrm{~mm}$.

Impacts of climate change on hydrologic water balance of different aquifers in the West Bank are illustrated in Table 3. The table shows the result of hydrologic simulations of the changes in the water budget for different aquifers occurring from climate change as represented by increased temperature and reduced precipitation. A $10 \%$ reduction in annual precipitation will result in reducing natural recharge of groundwater aquifers from 636 to $516 \mathrm{mcm} /$ year: a relative reduction of about $19 \%$. The largest reduction is expected to occur in the eastern aquifer, which will reach $24 \%$ as shown in Table 4 . The reduction in the annual natural recharge in the eastern aquifer is the largest among the three aquifers because precipitation over this aquifer is lower than other aquifers.

As shown in Table 3 and Table 4, the increase in temperature will have small effects on the water budget. The overall reduction in natural recharge due to an increase of $3^{\circ} \mathrm{C}$ in temperature is about $10 \%$. However, the effect of 3 degrees increase in temperature resulted in a reduction of $13 \%$ in the recharge of the 


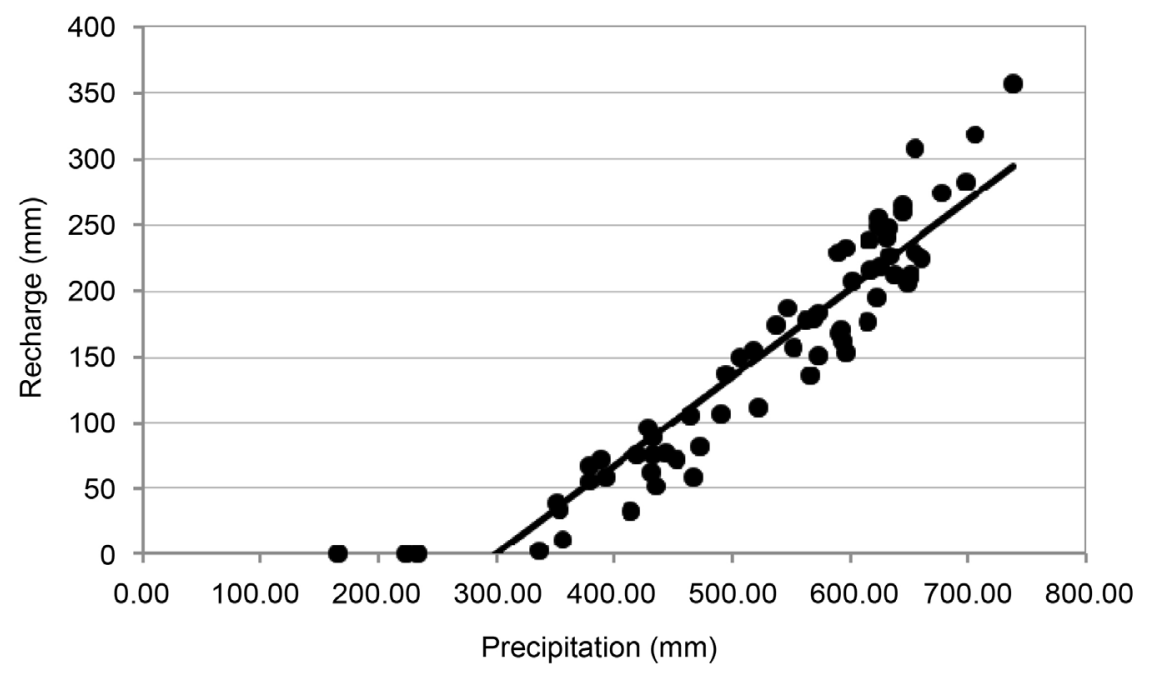

Figure 3. Annual recharge as function of annual precipitation for existing conditions.

eastern aquifer which has recharge areas with less precipitation and higher temperature.

The results shown in Table 3 and Table 4 show that the impacts of climate change on natural recharge of aquifers will vary from one area to another depending on the climatic conditions of the recharge areas. The analyses show that the reduction in recharge will be more severe in areas with drier and warmer climate. To understand the impacts of climate change on natural recharge of aquifers, monthly precipitation and evapotranspiration with potential changes due to climate change during the winter months were plotted at three climatic stations of intermediate locations in the recharge zones of the three aquifers under consideration. These plots are shown in Figures 4-6.

Figures 4-6 show the trend of variabilities in monthly evapotranspiration and precipitation at a selected number of weather stations representing the different climatic zones of the recharge areas of the three main aquifers in the West Bank. As indicated by these weather stations (Figures 4-6), average monthly precipitation exceed evapotranspiration during December, January and February in nearly all of the West Bank. Natural recharge of groundwater is expected to occur from excess precipitation during these three winter months. However, monthly precipitation excess over monthly evapotranspiration varies significantly in the three figures. The reduction in monthly precipitation and increase in evapotranspiration due to temperature increase show that the relative reduction in precipitation excess in Figure 6 (the eastern aquifer) is more than that in Figure 4 and Figure 5. This explains the increased effect of climate change on the recharge of the eastern aquifer which is located in a drier and warmer area. Thus, the effects of climate change become more severe when the aridity increases in the recharge zones of aquifers.

\section{Adaptation and Response to Climate Change}

As discussed above, Palestine suffers from existing water shortages, especially in 
Table 3. Water budget under different climate change scenarios in MCM/year.

\begin{tabular}{|c|c|c|c|c|c|c|c|c|c|}
\hline & Aquifer & Precipitation & Olives & Grapes & $\begin{array}{l}\text { Field } \\
\text { crops }\end{array}$ & $\begin{array}{c}\text { Irrigated } \\
\text { lands }\end{array}$ & Pasture & Runoff & Recharge \\
\hline \multirow{4}{*}{$\begin{array}{c}2^{\circ} \mathrm{C} \\
\text { increase in } \\
\text { temperature }\end{array}$} & $\begin{array}{l}\text { North } \\
\text { eastern }\end{array}$ & 520.1 & 143.4 & 0.0 & 87.3 & 4.9 & 114.6 & 38.2 & 131.6 \\
\hline & West & 1015.3 & 286.4 & 18.2 & 20.6 & 28.1 & 272.5 & 79.3 & 310.2 \\
\hline & Eastern & 938.3 & 119.1 & 6.8 & 31.1 & 29.2 & 550.3 & 49.7 & 152.0 \\
\hline & Total & 2473.7 & 549.0 & 24.9 & 139.1 & 62.2 & 937.4 & 167.2 & 593.9 \\
\hline \multirow{4}{*}{$\begin{array}{c}3^{\circ} \mathrm{C} \\
\text { increase in } \\
\text { temperature }\end{array}$} & $\begin{array}{l}\text { North } \\
\text { eastern }\end{array}$ & 520.1 & 145.0 & 0.0 & 88.0 & 4.9 & 116.6 & 38.2 & 127.4 \\
\hline & West & 1015.3 & 290.3 & 18.4 & 20.8 & 28.4 & 277.2 & 79.3 & 301.0 \\
\hline & Eastern & 938.3 & 120.1 & 6.9 & 31.3 & 29.3 & 556.2 & 49.7 & 144.7 \\
\hline & Total & 2473.7 & 555.4 & 25.2 & 140.1 & 62.6 & 950.0 & 167.2 & 573.1 \\
\hline \multirow{4}{*}{$\begin{array}{l}\text { 3\% reduction } \\
\text { in annual } \\
\text { precipitation }\end{array}$} & $\begin{array}{c}\text { North } \\
\text { eastern }\end{array}$ & 504.5 & 138.7 & 0.0 & 84.2 & 4.8 & 109.2 & 37.1 & 130.6 \\
\hline & Western & 984.9 & 269.7 & 17.7 & 19.7 & 27.1 & 253.3 & 76.9 & 320.6 \\
\hline & Eastern & 910.1 & 114.5 & 6.6 & 29.8 & 28.4 & 527.2 & 48.2 & 155.4 \\
\hline & Total & 2399.5 & 522.8 & 24.3 & 133.6 & 60.3 & 889.7 & 162.2 & 606.6 \\
\hline \multirow{4}{*}{$\begin{array}{l}6 \% \text { reduction } \\
\text { in annual } \\
\text { precipitation }\end{array}$} & $\begin{array}{c}\text { North } \\
\text { eastern }\end{array}$ & 488.9 & 137.2 & 0.0 & 82.4 & 4.8 & 108.0 & 35.9 & 120.7 \\
\hline & Western & 954.4 & 262.5 & 17.6 & 19.2 & 26.9 & 249.9 & 74.5 & 303.8 \\
\hline & Eastern & 882.0 & 112.2 & 6.6 & 29.0 & 27.7 & 517.2 & 46.8 & 142.6 \\
\hline & Total & 2325.3 & 511.8 & 24.2 & 130.6 & 59.4 & 875.0 & 157.2 & 567.1 \\
\hline \multirow{4}{*}{$\begin{array}{l}10 \% \\
\text { reduction in } \\
\text { annual } \\
\text { precipitation }\end{array}$} & $\begin{array}{l}\text { North } \\
\text { eastern }\end{array}$ & 468.1 & 134.7 & 0.0 & 79.8 & 4.7 & 106.3 & 34.4 & 108.1 \\
\hline & Western & 913.8 & 251.7 & 17.5 & 18.5 & 26.7 & 245.3 & 71.4 & 282.6 \\
\hline & Eastern & 844.4 & 108.9 & 6.6 & 28.0 & 26.7 & 503.5 & 44.8 & 126.0 \\
\hline & Total & 2226.3 & 495.3 & 24.1 & 126.3 & 58.1 & 855.2 & 150.5 & 516.8 \\
\hline \multirow{4}{*}{$\begin{array}{l}15 \% \\
\text { reduction in } \\
\text { annual } \\
\text { precipitation }\end{array}$} & $\begin{array}{c}\text { North } \\
\text { eastern }\end{array}$ & 442.1 & 134.4 & 0.0 & 79.7 & 4.7 & 106.2 & 32.5 & 84.5 \\
\hline & Western & 863.0 & 251.7 & 17.5 & 18.5 & 26.7 & 245.3 & 67.4 & 235.8 \\
\hline & Eastern & 797.5 & 108.9 & 6.6 & 28.0 & 26.7 & 503.5 & 42.3 & 81.6 \\
\hline & Total & 2102.6 & 495.0 & 24.1 & 126.2 & 58.1 & 855.1 & 142.2 & 402.0 \\
\hline
\end{tabular}

Table 4. Relative changes in recharge under different climate change scenarios for the three aquifers.

\begin{tabular}{ccccccccc}
\hline & $\begin{array}{c}\text { Annual } \\
\text { Precip. } \\
(\mathrm{mm})\end{array}$ & $\begin{array}{c}2^{\circ} \mathrm{C} \text { Temp. } \\
\text { increase }\end{array}$ & $\begin{array}{c}{ }^{\circ} \mathrm{C} \text { temp. 3\% Precip. } \\
\text { increase }\end{array}$ & reduction & reduction. & 10\% Precip. & $\begin{array}{c}15 \% \\
\text { reduction } \\
\text { Precip. } \\
\text { reduction }\end{array}$ \\
\hline North eastern & 546 & $6.1 \%$ & $9.1 \%$ & $6.8 \%$ & $13.9 \%$ & $22.9 \%$ & $39.7 \%$ \\
Western & 564 & $5.6 \%$ & $8.4 \%$ & $2.4 \%$ & $7.5 \%$ & $14.0 \%$ & $28.2 \%$ \\
Eastern & 327 & $8.8 \%$ & $13.2 \%$ & $6.8 \%$ & $14.4 \%$ & $24.4 \%$ & $51.0 \%$ \\
Total & 440 & $6.5 \%$ & $9.8 \%$ & $4.5 \%$ & $10.7 \%$ & $18.7 \%$ & $36.7 \%$ \\
\hline
\end{tabular}




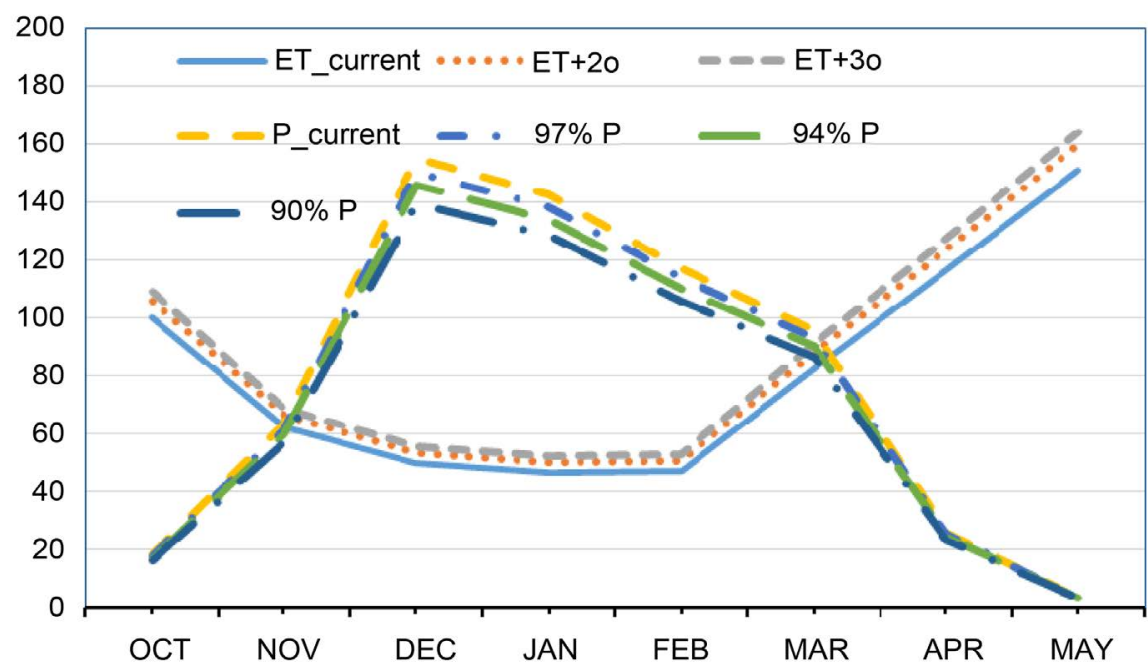

Figure 4. Changes in monthly precipitation and evapotranspiration at a climatic station (Ramallah) within the recharge areas of the western aquifer for: (a) existing climate conditions, (b) $2^{\circ} \mathrm{C}$ and $3{ }^{\circ} \mathrm{C}$ increase in temperature, (c) reduction of $3 \%, 6 \%$ and $10 \%$ in annual precipitation.

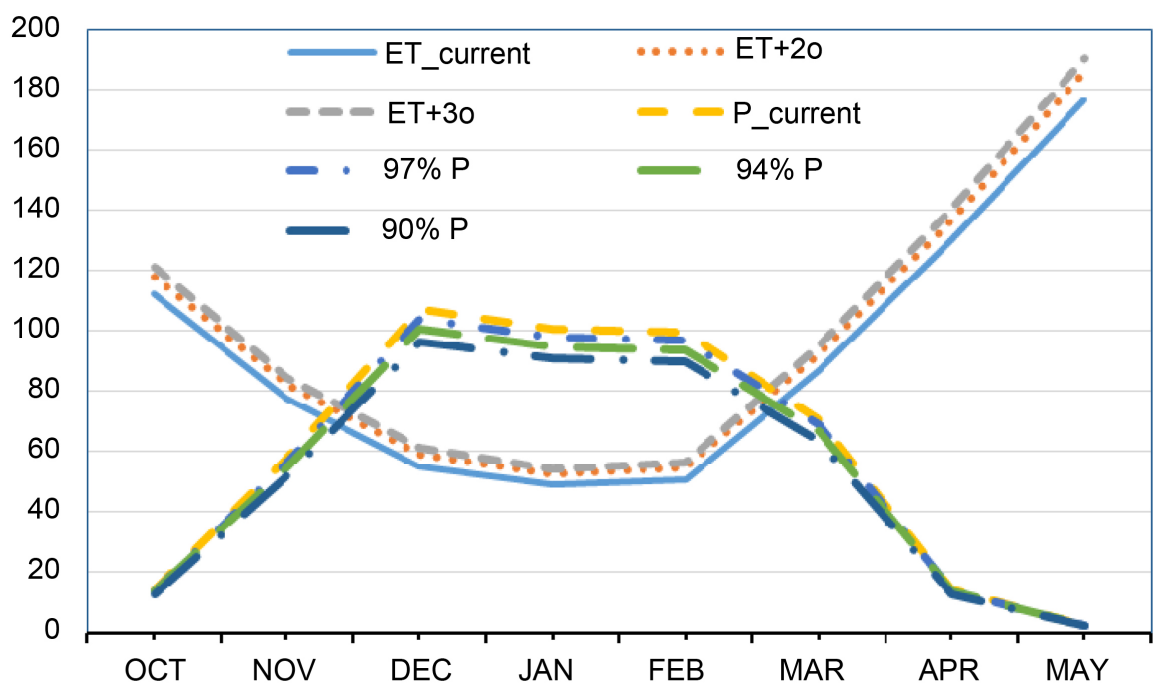

Figure 5. Changes in monthly precipitation and evapotranspiration at a climatic station (Jenin) within the recharge areas of the North eastern aquifer for: (a) existing climate conditions, (b) $2^{\circ} \mathrm{C}$ and $3{ }^{\circ} \mathrm{C}$ increase in temperature, (c) reduction of $3 \%, 6 \%$ and $10 \%$ in annual precipitation.

the Gaza strip. The increase in water demands, water shortages are expected to increase, requiring evaluating options to satisfy water demands, such as management and utilization of unconventional water resources. Climate change will result in a significant reduction of available water sources, thus increasing water shortages and negatively affecting socio-economic development. Considering the existing political and socio-economic situations in the area, the impacts of climate change on water resources are expected to affect existing and planned allocations of water among water users. Moving water from agricultural use to domestic use 


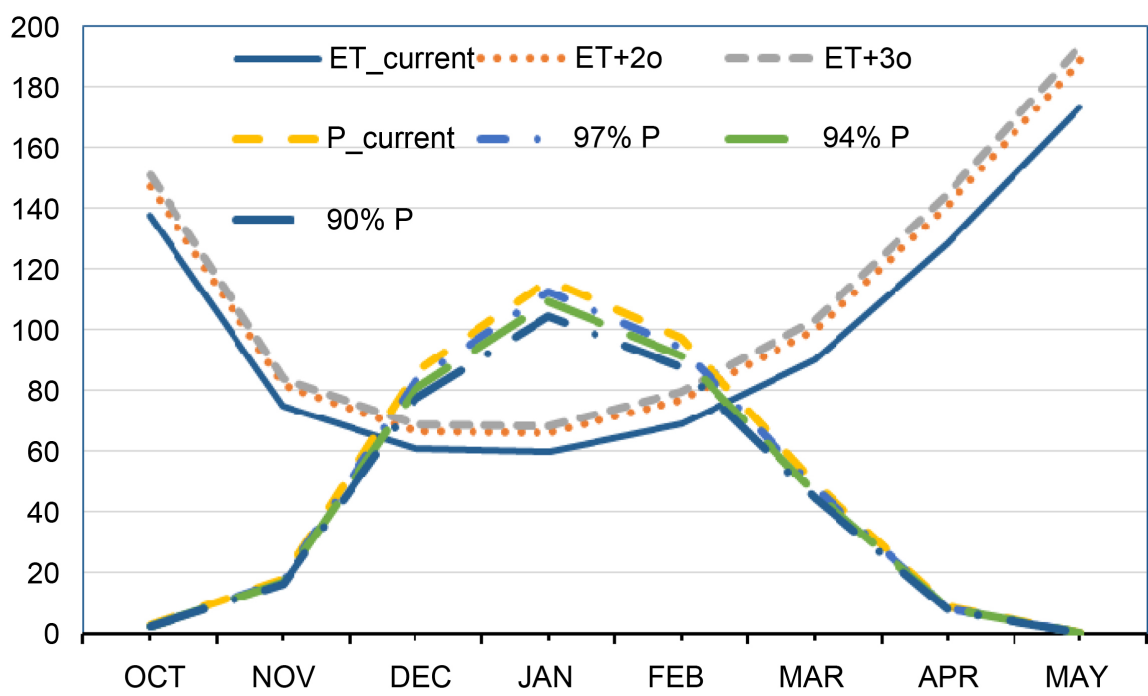

Figure 6. Changes in monthly precipitation and evapotranspiration at a climatic station (Doma) within the recharge areas of the eastern aquifer for: (a) existing climate conditions, (b) $2^{\circ} \mathrm{C}$ and $3{ }^{\circ} \mathrm{C}$ increase in temperature, (c) reduction of $3 \%, 6 \%$ and $10 \%$ in annual precipitation.

affects the socio-economic conditions of vulnerable communities and potentially slows the economic development of poor rural communities (many of which live in the drier areas in the eastern side of the West Bank). In addition to that, the reduction of water availability due to climate change requires regional cooperation and planning to prevent potential escalation of the conflict over water allocations in the area.

The status of existing and potential options and measures for adaptation to climate change in the area are discussed through the following:

1) Understanding and recognizing climate change effects on water resources:

The Middle East and North Africa (MENA) region is known as one of the hot spots for worsening extreme drought and aridity conditions under climate change [11]. Considering the limited available scientific literature concerning climate change in the area, there is a recognition for the impacts of climate change on water resources within the scientific community, the decision makers and concerned local and international organizations. This recognition could be seen from the work of international organizations such UNDP [12]. The UNDP work targeted at developing a climate change adaptation strategy and program of action for Palestine through stakeholders involvement and participation.

Although there have been many studies in the area concerning water resources, aridity, desertification and agriculture, research and studies concerning climate change impacts and adaptation to climate change were limited in Palestine as well as in the Middle East. Thus, there is a need for more research work there to develop and adapt models to better understand and quantify the effects of climate change on precipitation and temperature. In addition to that investigating and developing new options and alternatives for climate change adaptation. 
2) National policies and strategies concerning adaptation to climate change:

Understanding and recognizing the impacts of climate change should be followed by developing national and regional policies to adapt to the change and improve resilience of communities to such change. The Palestinian water sector strategy [13] [14] consolidates good governance for water through restructuring water sector bodies, improving water infrastructure, integrated management of water and wastewater, development of alternative sources of water including desalination of sea and brackish water, improving utilization of rainfall and surface water sources. The Palestinian agricultural sector strategy [15] [16] was more direct in acknowledging climate change and its impacts on increasing water demands and causing higher incidence of drought.

In addition to developing the strategies, the international organizations are assisting the Palestinian authority in building its capacities in planning and adapting to climate change. The UNDP assistance to develop strategies and action plans to combat desertification [17] and climate change adaptation [12] is a clear example of such support.

3) National knowledge and experience in developing adaptation methods and strategies:

Historic forms of household and local community coping in the face of climate and other hazards offer potential templates for adaptation to climate change in the area [12]. Considering the frequent droughts, the long summer dry months and the large variabilities in rainfall over time and space, the local communities developed indigenous knowledge and local experience in adapting to such conditions. The indigenous practices of water, soil conservation and management could be enhanced by newer technological options to improve water use efficiency and precision agricultural methods introduced in the area.

4) Potential adaptation measures and options include:

- Increasing local rainfall interception capacity;

- Incorporating climate risks;

- Increasing the use of non-conventional water resources (sea water desalination and treated wastewater reuse);

- Increasing the use of water harvesting;

- Incorporation of climate adaptation in land use planning;

- Selecting crops that are more tolerant to heat, salinity and drought;

- Prioritization of irrigation for highest value crops;

- Public participation and involvement;

- Water demand management through:

o Improving existing water infrastructure to reduce water loss;

o Improving the institutional setup for efficient management of water resources;

o Adjusting water tariffs to encourage users in conserving water;

o Improving water resource monitoring to improve understanding of sources and allow more optimal utilization. 


\section{Conclusions and Recommendations}

The study found out that a $10 \%$ reduction in annual rainfall as a result of climate change will have severe effect on ground water recharge. The reduction in the recharge due to $10 \%$ rainfall reduction is expected to range from $14 \%$ to $24 \%$. The impacts of a $15 \%$ reduction in annual precipitation will be very severe reaching $28 \%$ to $50 \%$. The effect of increase in temperature is expected to be also significant but less than that of rainfall reduction. The effect of a 3-degree centigrade increase in temperature could cause a reduction in annual recharge between $8 \%$ and $13 \%$. The impacts of climate change on aquifer recharge will vary according to the climatic conditions of the recharge area. The study showed that the reduction in annual recharge for the eastern aquifer will exceed that of the western aquifer due to the lower rainfall and higher temperature observed over this aquifer. Thus, the impacts of climate change on water resources availability will vary from one place to another even in a small country as Palestine. More severe effects on water availability will be expected in drier and warmer areas. These areas usually suffer from water shortages considering their aridity. Thus, the impacts of climate change on aquifer recharge will increase with increasing the aridity of the area. The overall effects of climate change will be severe on water resources availability negatively affecting the socio-economic conditions of people there and reducing stability in the area through potentially escalating exiting conflicts over water.

It was observed that local research on climate change is scarce although the understandings of climate change impacts are high. The national policies and strategies emphasize improved management and governance of water resources which will help in improving the resilience of the community to climate change. The involvement of international organizations assisted the local authorities in developing strategies and action plans to adapt to climate change and combat desertification. High priority adaptation options to climate change included: local increases in rainfall interception capacity, incorporating climate risks in planning and management, increasing the use of non-conventional water sources such as desalination of sea water and treated wastewater, increasing the use of water harvesting, incorporation of climate adaptation in land use planning, selecting crops that are more tolerant to heat, salinity and drought, prioritization of irrigation for the highest value crops, and water demand management options. Public involvement and participation are essential for adaptation measures to succeed.

\section{References}

[1] Palestinian Water Authority (PWA) (2012) Annual Status Report on Water Resources, Water Supply and Wastewater in the Occupied State of Palestine 2011.

[2] MFA (1995) Israel Ministry of Foreign Affairs, the Israeli-Palestinian Interim Agreement-Annex III.

http://mfa.gov.il/MFA/ForeignPolicy/Peace/Guide/Pages/THE\%20ISRAELI-PALES 


\section{TINIAN\%20INTERIM\%20AGREEMENT\%20-\%20Annex\%20III.aspx}

[3] Palestine Central Bureau of Statistics (PCBS) (2013) Summary of Demographic Indicators in the Palestinian Territory by Region.

[4] Intergovernmental Panel on Climate Change Working Group I (2007) Climate Change 2007: The Physical Science Basis. Geneva, Switzerland

[5] IPCC (2013) Summary for Policymakers. In: Stocker, T.F., Qin, D., Plattner, G.-K., Tignor, M., Allen, S.K., Boschung, J., Nauels, A., Xia, Y., Bex, V. and Midgley, P.M., Eds., Climate Change 2013: The Physical Science Basis. Contribution of Working Group I to the Fifth Assessment Report of the Intergovernmental Panel on Climate Change, Cambridge University Press, Cambridge, United Kingdom and New York, NY, USA.

[6] Christensen, J.H., Krishna Kumar, K., Aldrian, E., An, S.-I., Cavalcanti, I.F.A., de Castro, M., Dong, W., Goswami, P., Hall, A., Kanyanga, J.K., Kitoh, A., Kossin, J., Lau, N.-C., Renwick, J., Stephenson, D.B., Xie, S.-P. and Zhou, T. (2013) Climate Phenomena and Their Relevance for Future Regional Climate Change. In: Stocker, T.F., Qin, D., Plattner, G.-K., Tignor, M., Allen, S.K., Boschung, J., Nauels, A., Xia, Y., Bex, V. and Midgley, P.M., Eds., Climate Change 2013: The Physical Science Basis. Contribution of Working Group I to the Fifth Assessment Report of the Intergovernmental Panel on Climate Change, Cambridge University Press, Cambridge, United Kingdom and New York, NY, USA.

[7] Iglesias, A., Garrote, L., Diz, A., Schlickenrieder, J. and Martin-Carrasco, F. (2011) Re-Thinking Water Policy Priorities in the Mediterranean Region in View of Climate Change. Environmental Science and Policy, 14, 744-757. https://doi.org/10.1016/j.envsci.2011.02.007

[8] FAO (2013) CropWat for Windows Version: Users Guide. Food and Agriculture Organization. http://www.fao.org/nr/water/infores_databases_cropwat.html

[9] Allen, R., Pereira, L., Raes, D. and Smith, M. (1998) Crop Evapotranspiration (Guidelines for Computing Crop Water Requirements). FAO Irrigation and Drainage Paper No. 56, FAO, Rome, Italy.

[10] Guttman, J. and Zukerman, H. (1995) Flow Model in the Eastern Basin of the Judea and Samaria Hills. Tel-Aviv: Tahal Consulting Engineers Ltd., 01/95/66.

[11] Katharina, W., Linda, K., Sophie, A. and Carl-Friedrich, S. (2017) Climate Change Impacts in the Middle East and Northern Africa (MENA) Region and Their Implications for Vulnerable Population Groups. Regional Environmental Change.

[12] UNDP (2010) Climate Change Adaptation Strategy and Programme of Action for the Occupied Palestinian Territory. United Nations Development Programme, Programme of Assistance to the Palestinian People. Jerusalem.

[13] PWA (2014) National Strategy for Water and Wastewater in Palestine. http://www.pwa.ps

[14] PWA (2016) Strategic Plan for the Water Authority 2016-2018. (In Arabic) http://www.pwa.ps

[15] Ministry of Agriculture (MOA) (2011) National Agriculture Sector Strategy, "Shared Vision Strategy" 2011-2013. Ramallah, Palestine.

[16] Ministry of Agriculture (MOA) (2014) National Agriculture Sector Strategy, Resilience and Development" 2014-2016. Ramallah, Palestine.

[17] UNDP (2012) The National Strategy, Action Programme and Integrated Financing Strategy to Combat Desertification in the Occupied Palestinian Territory. United Nations Development Programme, Programme of Assistance to the Palestinian People. Jerusalem. 